\title{
Sağlıkta eşitsizliklerle ilgili temel kavramlar
}

\author{
Hatice Şimşeka, Bülent Kılıçb
}

\section{Özet}

Sağlıkta eşitsizlik, sağlı̆̆a etki eden sosyal etmenlerin ve/veya sağlık sistemindeki yetersizliklerin etkisiyle bireylerin ve/veya toplumun sağlığında önlenebilir ve kabul edilemez bozulmaların oluşmasıdır. Neoliberalizmin yaygınlaşmasından sonra günümüzün başlıca konuları arasındadır. Sağlıkta eșitsizliğin iki bileșeni vardır: sağlığın sosyal belirleyicilerindeki eşitsizlik ve sağlık hizmetlerindeki eşitsizlik. Sağlıkta eşitsizlik çalışmalarında standart bir değerlendirme yöntemi yoktur, pek çok bağımlı ve bağımsız değişken kullanılmaktadır. Çalışmalarda kullanılan başlıca bağımlı değișkenler sağlık durumuna (mortalite, morbidite, engellilik), sağlığı etkileyen risk etmenlerine, sağlık algısına, sağlık hizmetlerinin erişilebilirliğine ve kullanımına ilișkindir. Bağımsız değișken olarak temelde öğrenim, gelir, meslek, sosyal sınıf değișkenleri kullanılmaktadır. Konut özellikleri, sosyal güvence durumu, etnik yapı, yaşamı kolaylaştıııcı araçlar/dayanıklı tüketim mallarına sahip olma, bazı bireysel ve bölgesel eşitsizlik indeksleri de bağımsız değişken olabilmektedir. Sağlıkta eşitsizliklerin yalnızca sağlık hizmeti sunumu ile giderilmesi olası değildir. Sağlıkta eşitsizlikleri azaltmanın yolu sınıfsal farklılıkları azaltmak, sağlık hizmetlerini daha ulaşılabilir ve kapsayıcı hale getirmek olmakla birlikte temel çözüm sınıflı toplum yapısının ortadan kaldırılmasıdır.

Anahtar Kelimeler: Sağlık, eşitsizlik, sosyoekonomik durum, yoksulluk

\section{Basic concepts related to health inequalities}

\begin{abstract}
Health inequalities can be defined as the avoidable and unacceptable disruptions in the health of individuals or communities caused by social factors and/or deficiencies in the organization of the health system. It is among the main political/social topics today after the spread of neoliberalism. There are two main components of health inequality, inequality in the social determinants of health and inequality in health care. There is no Standard method used for evaluation in health inequality studies and many dependent and independent variables have beenused. The main dependent variables used in these studies are related to health status (mortality, morbidity, disability), perceived health, access to and use of health care. Basically, education, income, occupation and social class are used as independent variables. House ownership, social security status, ethnicity, ownership of durable goods, and some of the individual and regional inequality indexes can also be used as independent variables. It is unlikely that inequalities in health can be eliminated by providing only health care. Although ways to reduce health inequalities areto diminish class differences, to make health services more accessible and comprehensive, the main solution is to eliminate class structure of the population
\end{abstract}

Key Words: Health, inequality, socioeconomic status, poverty

a Öğr.Gör. Dr. Dokuz Eylül Üniversitesi Tıp Fakültesi Halk Sağlı̆̆ı Anabilim Dalı, İzmir

b Doç. Dr. Dokuz Eylül Üniversitesi Tıp Fakültesi Halk Sağlığı Anabilim Dalı, İzmir

Sorumlu Yazar: Hatice Şimşek, Dokuz Eylül Üniversitesi Tıp Fakültesi Halk Sağlığı Anabilim Dalı, İzmir. Tel: 0232 4124001, E-posta: hatice.simsek@deu.edu.tr

Geliş tarihi: 27 Aralık 2011, Kabul tarihi: 1 Temmuz 2012 


\section{Giriş}

Eşitlik ve eşitsizlik kavramları "her șey zıddıyla vardır" ilkesine uygun olarak tarihsel bir birliktelik içindedir. İnsanlık tarihinin eşitsizliklerle dolu geçmişi, insanın eşitliği arayışını yani eşitlik kavramını yaratır. Tarihsel olarak 16-18. yy.larda daha çok gündeme gelmesine karşın ortaya çıkışı 1789 Fransız Devrimi'ndeki "eşitlik", "kardeşlik", "özgürlük" üçlemesine dayanır. Temelinde feodaliteye ve burjuvaya karşı çıkış vardır. Feodalite yıkılırken eşitlik ön plana çıkmaya başlamıştır ${ }^{1}$. İnsanlık tarihindeki sınıfsal ayrıcalıklar, eşitsizlikler ve haksızlıklar onları hak ve adalet arayışına itmiş ve tarihsel olarak insanlığı eşitliğe götüren yolu açmıştır. İnsanlık tarihi için bu çok önemli bir gelişme olmakla birlikte temel kazanım yalnızca yasalar önünde yani biçimsel bir eşitlik ya da fırsat eşitliği olarak gelişmiştir ${ }^{2}$. Genelde insanlar eşitsizliklerin nedenlerini yok etmekten çok, sonuçlarını kabullenmeye ya da değiştirmeye çalışmışlardır. Ancak 18 ve 19. yy.da bazı bilim adamları bu konu hakkında bilimsel olarak çalışmaya başlamışlardır. Durkheim sosyal eşitsizliklerin ancak doğal eşitsizliklerin bir izdüşümü olduğunda kabul edilebilir olduğunu söylemiştir ${ }^{3}$. Marx ise kapitalist sistemin eşitsizlikleri yaratan temel neden olduğunu göstermiştir. Marx değer yasası ile $(\mathrm{d}=\mathrm{c}+\mathrm{v}+\mathrm{s})$ artı değeri ve sömürüyü tanımlamış ve eşitsizliğin temel nedeninin kapitalist üretim biçimi olduğunu matematiksel olarak ortaya koymuştur4.

"Sağlıkta eșitsizlik, doğal değil, toplumsal nedenlerden kaynaklanan; doğal nedenlerin ise ancak toplumsal nedenler dolayımıyla etki gösterdikleri; önlenebilir, önlenebilir olduğu için de kabul edilemez nitelikte olan; bireysel değil toplumsal bir bağlam içinde saptanması, ele alınması, incelenmesi, savaşılması gereken; bu nedenle de tüm bu süreçte ekonomi, sosyoloji, politika gibi sağlık dişı disiplinlerin de etkinliğinin gerektiği; yalnızca sosyal, politik ve ekonomik değil, aynı zamanda ahlaki bir sorun olarak da kavranması gereken; toplumsal gruplar arasındaki sağlıkla ilgili farklılıklardır"s.
Diğer bir tanımla sağlıkta eşitsizlik sağlığa etki eden sosyal etmenlerin ve/veya sağllk sistemindeki yetersizliklerin etkisiyle bireylerin ve/veya toplumun sağlığında önlenebilir ve kabul edilemez bozulmaların oluşmasıdır. Dolayısıyla sağlıkta eșitlik kavramı, eksikliklerinde eşitsizliğin oluştuğu iki önemli bileşenin (sosyal etmenler ve sağlık hizmetleri) toplamından oluşur:

1. Sağlık hizmetlerinde eşitlik: Herkesin, gereksinimi olduğu anda, gereksinimi olduğu kadar sağlık hizmeti alması yani eşit gereksinimler için eşit sağllk hizmeti sağlanmasıdır. Bu alanda eşitlik için sağlık hizmetlerinin organizasyonu ve sağlı sisteminin yapısı önem kazanır6. Sağlık sistemi insangücü, finansman, örgütlenme, yönetim, politika gibi temel yapı taşlarından oluşur. $\mathrm{Bu}$ bileşenlerin herhangi birindeki eksiklik sağllk hizmet sunumunda yetersizliğe ve eşitsizliklere yol açar.

\section{Sağlığın sosyal belirleyicilerinde} eşitlik: Sağlıkta eşitsizlikleri yaratan sosyal etmenlerin olumsuz etkilerini yani sosyal eşitsizlikleri kontrol etmek, en aza indirmek ya da ortadan kaldırarak sağlıkta eşitliği sağlamaktır7. Bu alandaki eşitlik, öğrenim, meslek, sınıf, gelir gibi sağlığın sosyal belirleyicileri üzerine toplumsal düzeyde yapılan girişimlerle sağlanır.

Sağlıkta eşitsizlikler yukarıda belirtilen iki bileșenin olumsuz yönde etkilenmesiyle oluşur. Temelinde kapitalist üretim ilişkilerinin yattığı bu karşılıklı etkileşim sonucunda gerek toplumsal ve sosyal yapı gerekse sağlık sistemi kar ilişkileri temelinde eşitsizlikler yaratacak şekilde etkilenir. Sosyal değişkenlerin ve sağlık sistemindeki değişkenlerin eşitsizlik yaratmaktaki ağırlıkları doğal olarak birbirinden farklıdır ve gerçekte birbirlerinden tam olarak ayrı bir etki göstermezler. Ancak dinamik ve birbirinden etkilenen kompleks bir yapı söz konusudur (Şekil 1). 


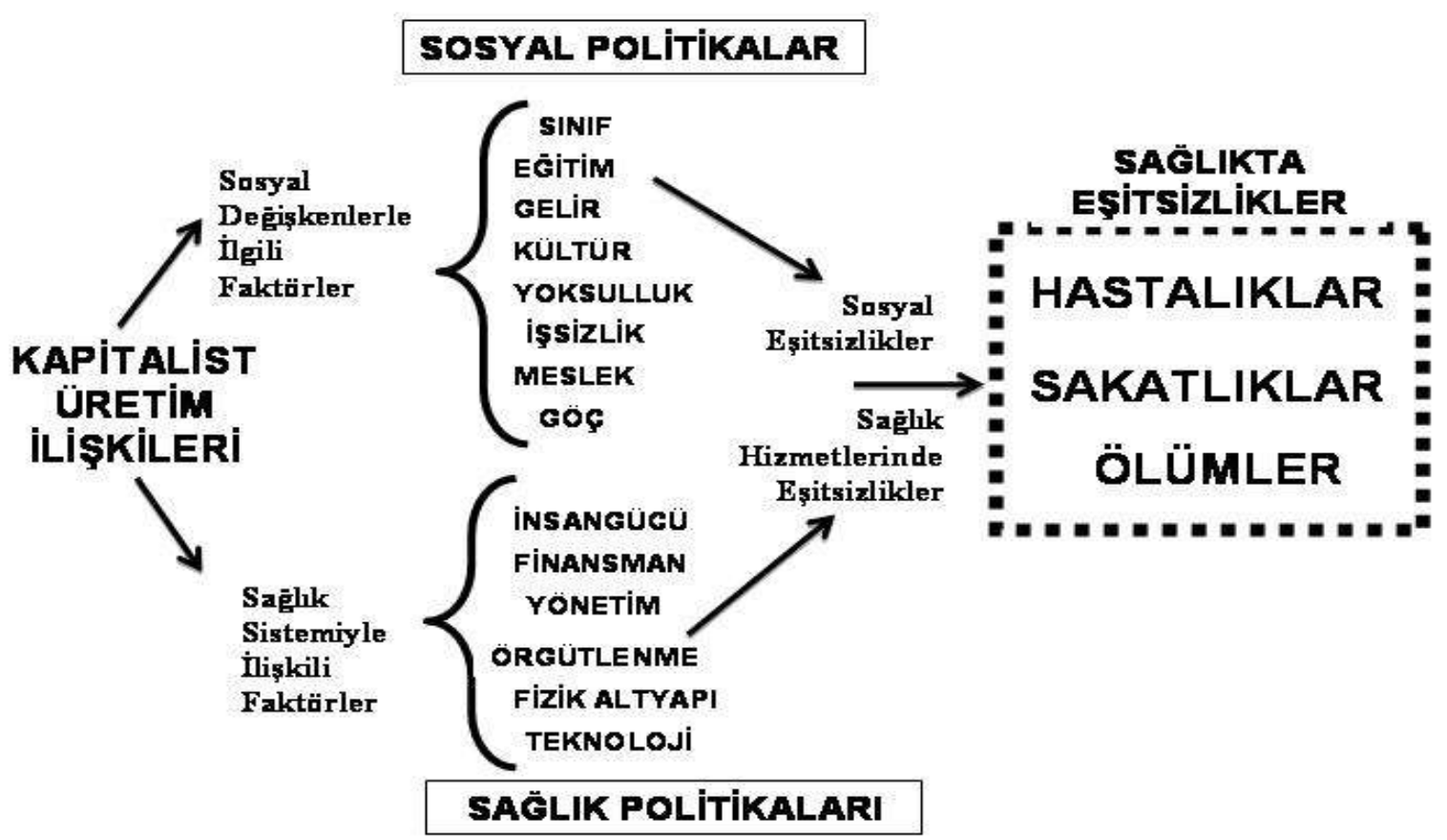

Şekil 1. Sağlıkta Eşitsizlikleri Oluşturan Temel Etmenler

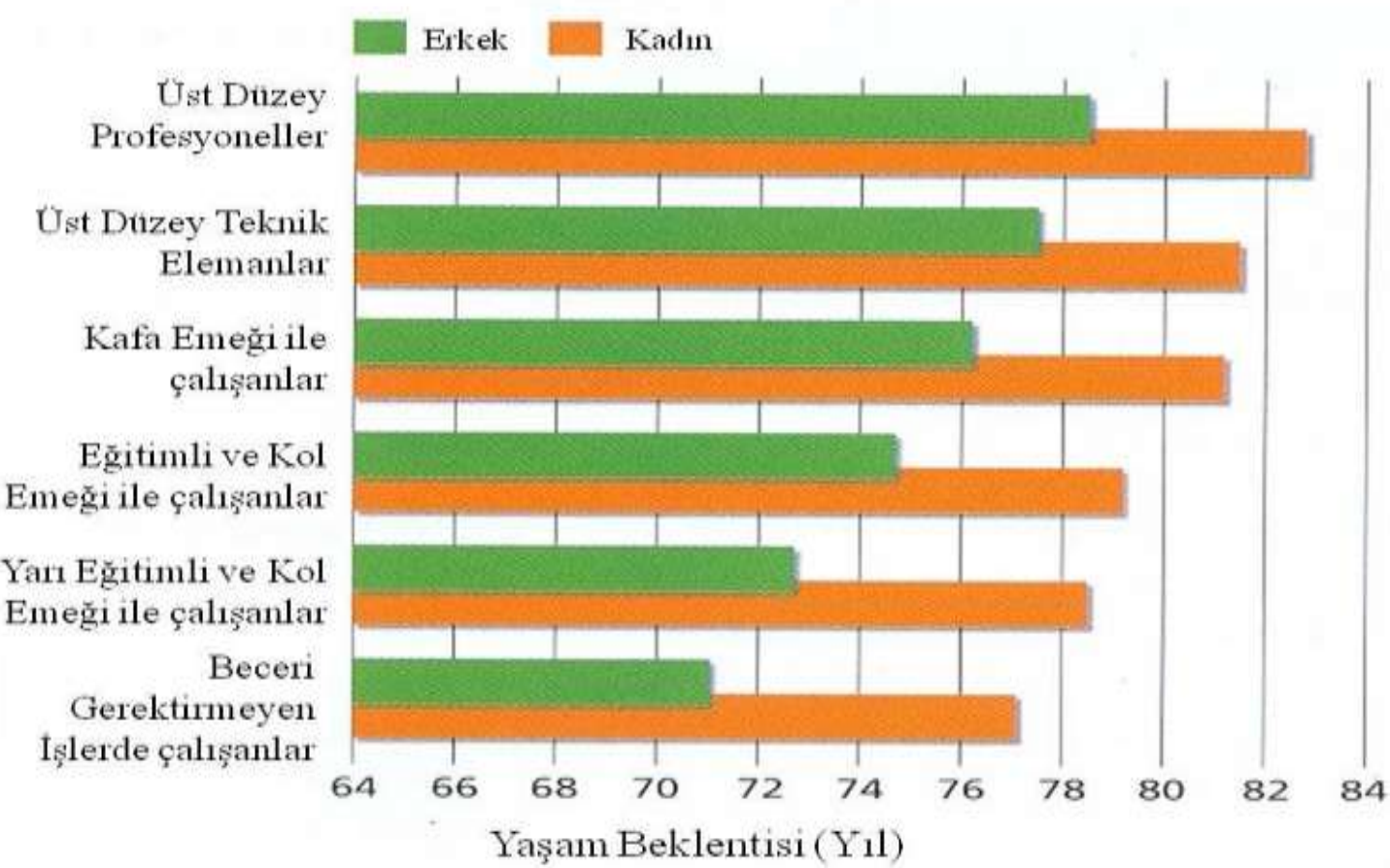

Şekil 2. İngiltere'de Mesleksel Sınıfa Göre Yaşam Beklentisi Farklılıkları (1997-99) (Kaynak: WHO, 2003:10) 
Burada önemli olan konu eşitsizliklerin salt sağlık hizmet sunumundaki eşitsizlikler ya da yalnızca sosyal eşitsizlikler olarak algılanmaması gerektiğidir. Sağlıkta eșitsizlikler bu iki yapının toplamıdır ve bu nedenle bu alanlardan yalnızca birisine önem vererek sağlıkta eşitlik sağlanamaz. Örneğin çok iyi bir sağlık sistemi oluşturulsa ve herkese eşit bir sağllk hizmeti götürülse bile sınıfsal farklılıklardan ötürü dezavantajlı gruplar daha fazla hastalanmakta ve daha erken ölmektedir. İngiltere'de gelir düzeyi farklılı̆̆ nedeniyle aynı yaş grubu ve cinsiyetteki yoksullar, zengin yaşıtlarından ortalama 5 yıl daha az yaşamaktadır. Bu farklılık ABD ve Almanya'da ortalama 4 yıldır. Benzer şekilde İngiltere'de sınıfsal farklılık nedeniyle alt ve üst sınıflar arasında erkeklerde 8 yıl, kadınlarda ise yaklaşık 6 yıl yaşam süresi farkı vardır ${ }^{8}$ (Şekil 2).

Yaş ve cinsiyet gibi kontrol edilemeyen etmenlerden kaynaklanan sonuçlar ise sağlıkta eşitsizlik değil "farklılık" olarak nitelendirilir9. Yani yaşlı bir erkeğin, genç bir erkeğe göre daha fazla kalp hastalığına yakalanma riski olması biyolojik yapıya bağlı bir farklılıktır, eşitsizlik değildir. Ancak yoksul bir erkekte aynı yaştaki zengin bir erkeğe göre daha fazla hastalık görülmesi sağlıkta eşitsizliktir çünkü doğaldır ki bu eşitsizlik önlenebilir. Aynı şekilde bir kadında biyolojik nedenlerle erkeklere göre bazı hastalıkların daha sik görülmesi bir eşitsizlik değildir. Ancak erkek çocuğa kız çocuktan daha fazla sağlık hizmeti sağlamak ya da cinsiyete bağlı olarak kadınlara yönelik negatif ayırımcılık yaparak kırsal alanda ev içinde kadının statüsünü düşürerek, daha kötü beslenmesine ya da sağlıksız koşullarda yaşamasına yol açmak eşitsizliktir.

Pek çok çalışmada coğrafya ya da etnik yapı doğrudan bir eşitsizlik nedeni olarak ele alınır. Belli coğrafi bölgelerde gelir dağılımının daha bozuk olması ya da yoksulluğun yaygınlığı etnik yapıya ya da coğrafyaya bağlanır. Oysa aynı coğrafyada ya da aynı etnik yapıdaki zenginler diğer etnik gruplardaki ya da bölgelerdeki zenginler gibi daha az hastalanır ve daha geç ölür. Örneğin Güneydoğu Anadolu Bölgesi'nde yaşayan zengin bir işveren, İzmir'de yaşayan yoksul bir işçiden daha sağlıklı yaşayabilir. Mısır, Sri Lanka ve Peru'da çocuk ölümlerinin daha düşük olduğu zengin semtlerde yoksul komşu çocuklarında (kapıcı çocukları) çocuk ölümleri daha yüksek çıkar ${ }^{10}$. Bu nedenle eşitsizliği doğuran temel etmenin bölgesel ya da etnik özellikler değil, sınıfsal yapı olduğu gözden kaçırılmamalıdır.

Eşitsizlikle ilgili en önemli nokta daha fazla gereksinimi olan grupların ödeme güçlüğü ya da bilgisizlik nedeniyle sağlık hizmetine erişememesi ya da daha yoksul bireylerin yaşadığı bölgelere daha az sağlık yatırımı yapılmasıdır. $\mathrm{Bu}$ durum özellikle daha fazla risk altında olan yoksul grupların sağlık hizmetine ulaşamamasına yol açar. "Ters Hizmet Kuralı" olarak adlandırılan bu durum eşitsizlikleri daha da artırır9.

Sağlıkta eşitsizlikler önümüze hastalıklar, ölümler ve yeti yitimleriyle çıkar. Görünürdeki nedenler yoksulluk, göç, işsizlik, eğitimsizlik, yanlış gelenekler/inançlar, açlık, sağlıksız gıda, konutsuzluk, savaş, terör, iş kazaları ve meslek hastalıkları gibi nedenlerdir. Ancak nedenlerin nedenleri dikkate alındığında yoksulluk, göç gibi sorunların gelir dağılımı bozukluğundan, iş kazaları ve meslek hastalıklarının çalışma koşullarından kaynaklandığı görülür. Daha da önemlisi tüm nedenlerin çıkış noktasına bakıldığında temel nedenin kapitalist üretim ilişkileri ve sınıflı toplum yapısı olduğu görülür. Örneğin savaşların temel nedeni yeni pazarlar yaratmak ve tıkanan ekonomilerin önünü açmaktır. Bunun gerçek nedeni ise sermayenin karını düşünen kapitalizmdir. Çalışma koşullarının değişmesi kapitalizmin değişik bir biçimi olan neoliberalizmin etkileriyle olur. Benzer şekilde kapitalist sistemde kar etme güdüsü eğitim sektörünün özelleşmesine bu da alt sinıflarda ve yoksullarda eğitim olanaklarına erişememeye yol açar. Sağlıkta eşitsizliklerin nedenleri özet olarak Şekil 3'deverilmiştir. 


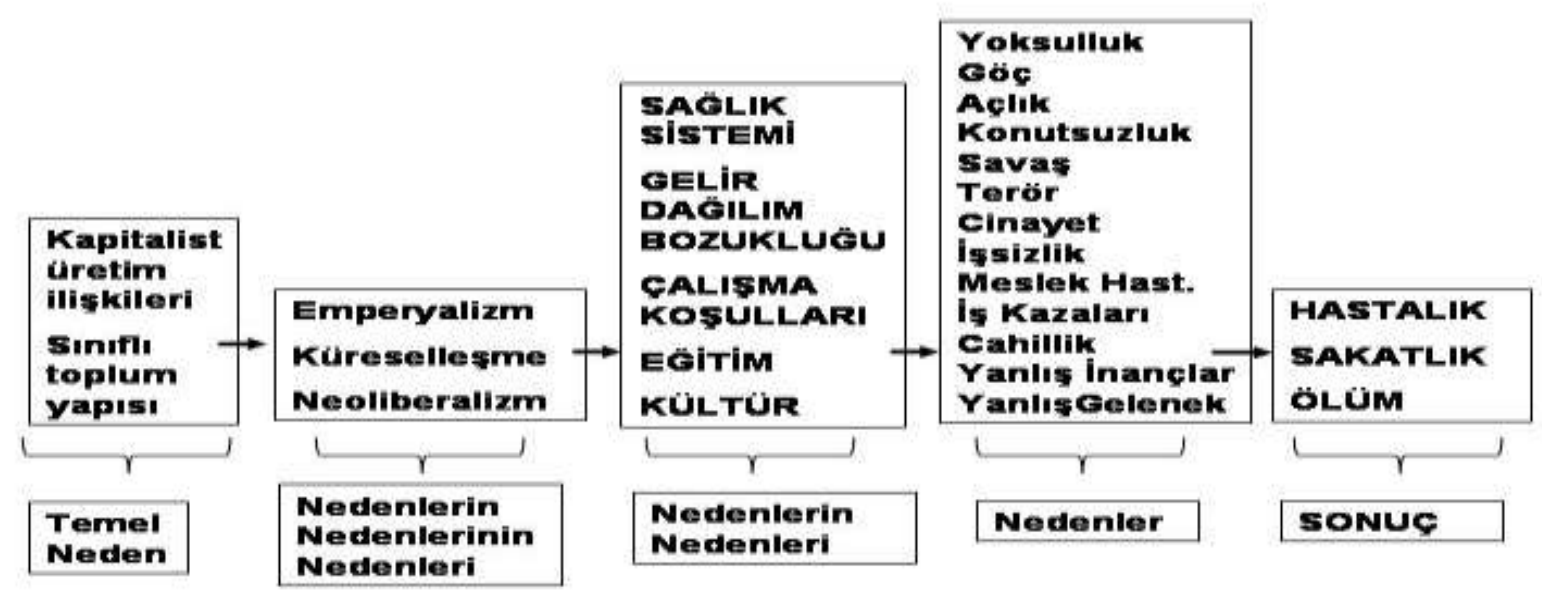

Şekil 3. Sağlıkta Eşitsizliklerin Nedenleri ve Temel Neden

Kapitalizm, her şeyi dolayısıyla sağlığı da bir meta olarak ele alır. Meta üretimi ise kapitalistlerin sermayeye artı değer aktaran bir üretim biçimidir. Tüm emekçiler (buna sağlık üretimi yapan sağlık emekçileri de dahildir) kendilerini çalıştıran sermayeye emeklerini satar, yaptıkları üretim sonucunda da elde edilen değerin bir kısmını ücret olarak alırlar. Ancak bu toplam üretim sonucunda kalan miktara (artı değere) sermaye sahibi tarafından el konulur. Bu nedenle kapitalizm zaten esas olarak eşitsizlikleri yaratan bir mekanizmaya sahiptir. Bu üretim ilişkisi temel olarak daha çok işin daha az işçi tarafından yapılmasina, ücretlerin düşürülmesine, işsizliğin bir baskı aracı olarak kullanılmasına neden olur. Tüm bu ilişkiler kapitalist sistemin neden olduğu görünür nedenleri (işsizlik, yoksulluk, iş kazaları, konut ve beslenme sorunları) ortaya çıkarır ${ }^{5}$. Bu ilișki Şekil 3'te özetlenmiştir.

\section{Terminoloji}

Eşitsizliklerin Türkçe terminolojisine ilişkin pek sıkıntı yoktur. Bir zamanlar eşitlik yerine "hakkaniyet" sözcügünün kullanımı denenmiş olsa da "eşitlik" ve zıddı olarak da "eşitsizlik" sözcükleri kullanılır. Oysa İngilizce'de eşitlik anlamına gelen iki ayrı sözcük vardır: equity (daha soyuttur, eşitliği tüm boyutlarıyla kapsar) ve equality (daha somuttur, mutlak eşitlik/salt eşitlik anlamına gelir). Bu sözcüklerin zıddı olarak da inequity ve inequality sözcükleri kullanılır. Sağlıkta eşitsizlik literatüründe İngilizce kaynaklarda "eşitsizlik" sözcügü genellikle "inequality" sözcüğü ile ifade edilir. Bunun temel nedeni eşitsizliklerin ölçülebilir yani rakamsal değerlerle gösterilebilir olmasıdır. Ancak son zamanlarda literatürde eşitsizlik için "inequity" sözcüğü de kullanılmaya başlanmıştır. Bunun nedeni eşitlik kavramının "equality" değil "equity" sözcüğü ile ifade edilmesidir. Equity sözcügü, rakamsal bir eșitlik değil sosyal etmenlerde ve sağlık hizmetlerindeki gereksinimlerden kaynaklanan geniş kapsamlı yani gerçek eşitlik anlayışını ifade eder. Sonuç olarak eșitlik için literatürde çoğunlukla tek bir sözcük "equity" kullanılırken, eşitsizlikleri ifade ederken iki ayrı sözcük de (inequity ve inequality) kullanılabilir. Ancak literatürde eşitsizlikler denilince daha çok inequality sözcüğünün geçtiği dikkate alınmalıdır.

\section{Sağlıkta eşitsizliklerin ölçümü}


Sağlıkta eşitsizliklerin ölçümü iki alt başlık altında incelenebilir:

a) Sağlık durumuna ilişkin eşitsizlikler: $\mathrm{Bu}$ alanda kullanılan başlıca -bağımlıdeğişkenler mortalite, morbidite, engellilik, sağlığ etkileyen risk etmenleri, sağlık algısı, sağlık hizmetlerinin erişilebilirliği ve kullanımı ile ilişkili değişkenlerdir. $\mathrm{Bu}$ değişkenlerden bazıları (risk etmenleri, algılanan sağlık vb) aynı zamanda bağımsız değișken olarak da kullanılabilir (Şekil 4).

\section{ANA BAĞIMSIZ DEĞİSTKNLER}

Sosyo-ekonomik Durum

(Öğrenim, Gelir, Sınıf)

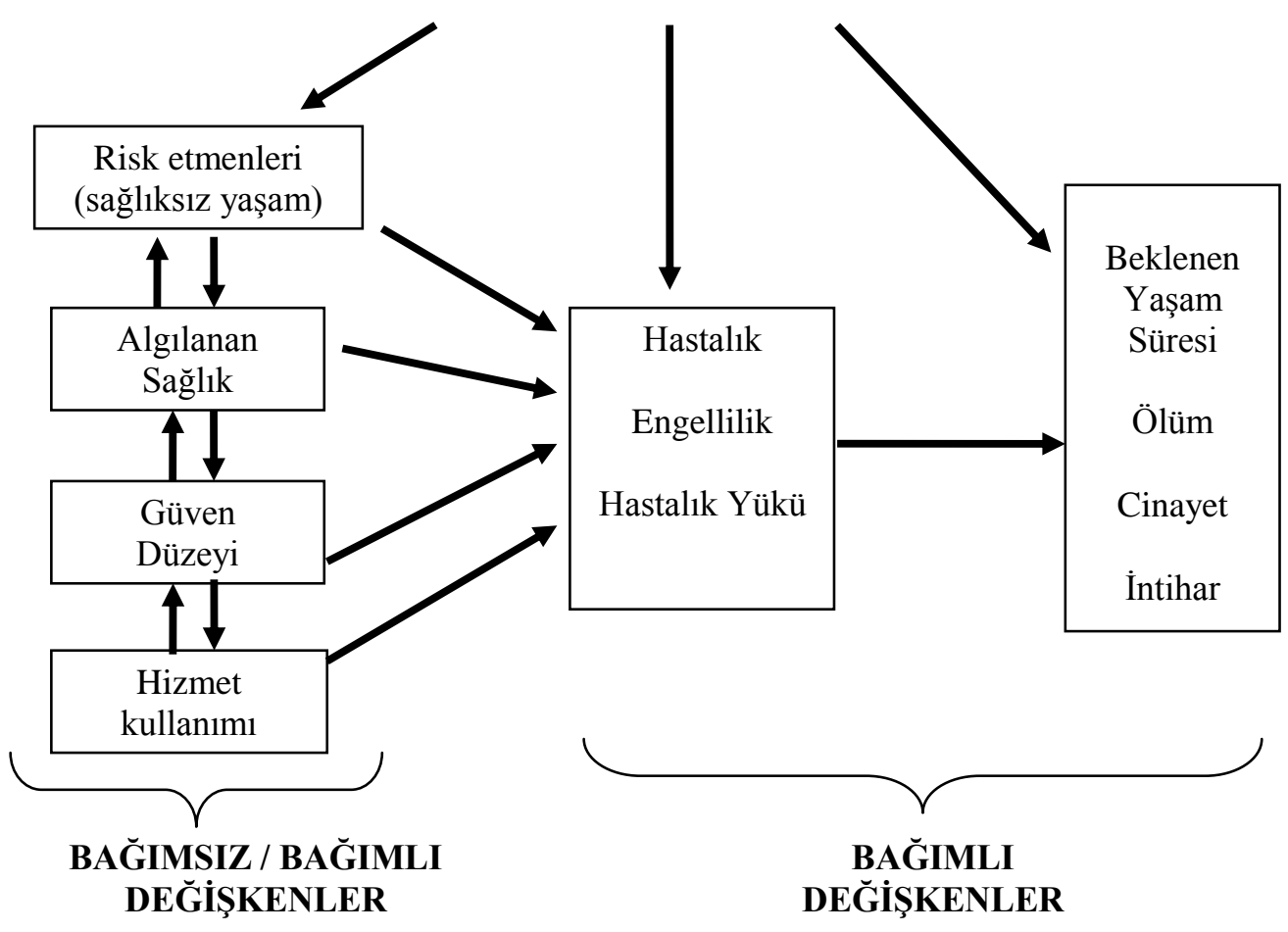

Şekil 4. Sağlıkta Eşitsizliklerle İlgili Çalışmalarda Kullanılan Değişkenler

Eşitsizliklerle ilgili çalışmalarda şiddet (cinayet) ve insanların birbirine güven düzeyi de son zamanlarda kullanılmaya başlanan bağımlı değişkenlerdendir ${ }^{11}$. Bu alanda kullanılan çok sayıda bağımlı değişken Tablo 1'de özetlenmiştir. 
Tablo 1. Sağlıkta Eşitsizlik Çalışmalarında En Çok Kullanılan Bağımlı Değişkenler

\begin{tabular}{|l|l|}
\hline ANA BAŞLIK & BAĞIMLI DEĞiŞKEN \\
\hline Hastalık/ Engellilik & $\begin{array}{l}\text { Hastalık varlığı, komorbidite, akıl sağlığı (depresyon, } \\
\text { kaygı, algılanan sağlı, engellilik, yeti yitimi, yaşam } \\
\text { kalitesi, günlük yaşam aktiviteleri, ilaç kullanımı, } \\
\text { polifarmasi, obezite, DALY, QALY }\end{array}$ \\
\hline Ölüm & $\begin{array}{l}\text { Ölüm hızları, ölüm nedeni, bebek ölümleri, sağkalım, } \\
\text { beklenen yaşam süresi, cinayet, intihar }\end{array}$ \\
\hline Risk etmenleri/ Sağlık davranışları & $\begin{array}{l}\text { Sigara, alkolizm, madde kullanımı, fizik aktivite yokluğu, } \\
\text { beslenme alışkanlıkları, sağlıklı içme suyuna ulaşım, } \\
\text { adölesan gebelik, korunmasız cinsel ilişki }\end{array}$ \\
\hline Hizmet kullanımı & $\begin{array}{l}\text { Sağlık hizmetlerinin varlığı, coğrafi-finansal-kültürel } \\
\text { ulaşllabilirliği, kapsamı, kullanımı ve niteliği }\end{array}$ \\
\hline Güven Düzeyi & Güven duymama, düşmanlık skoru, mutluluk skoru \\
\hline
\end{tabular}

b) Sosyo-ekonomik etmenlere bağlı eşitsizlikler: Sağlıkta eşitsizlikleri sosyal faktörler açısından açıklamaya çalışan çok sayıda teori vardır (davranışsal, kültürel, psikososyal, materyalist teoriler vb) ${ }^{12}$. Ancak yapılan tüm çalışmalarda eșitsizliklerin belirlenmesinde sıklıkla gelir durumu ile sağlık durumu arasındaki ilişki incelenir ${ }^{11}$. Oysa sosyal tabakalanma ya da hiyerarşinin en temel belirleyicisi sayılan sosyo-ekonomik düzey (SED), sağlıkta eşitsizlik çalışmalarında da kullanılan öncelikli bağımsız değişkendir. SED'in esas belirleyicisi ise sinıfsal yapıdır. Sinıfsal yapıya ilişkin Marx ve Weber'e ait iki görüş bulunur. Marx'a göre sinıf bireyin üretim araçlarına sahip olma durumuna bağlıdır. Weberci yaklaşımda ise sınıf bireylerin tüketici özelliklerine bağlıdır ${ }^{5}$. Weberci yaklaşımda bireylerin sosyal hiyerarşi içindeki konumları piyasa ilişkileri içindeki konumları ile belirlenir ve bu konumu belirleyen üç temel değişken gelir, öğrenim durumu ve meslektir ${ }^{13}$.

Öğrenim durumu gelecekteki iş ve gelir olanakları için belirleyici özellikte olması, kişinin bilgiye erişme olanaklarına ilişkin bilgi vermesi, ekonomik olarak aktif olsun ya da olmasın herkes için kullanılabilir bir değişken olması, gençlik dönemi sonrasında genellikle değişmemesi, ölçümünün güvenli ve güvenirliğinin yüksek olması, hastalık durumundan etkilenmemesi ve uluslararası karşılaştırmalara görece uygun olması nedeniyle kullanımı avantajlı bir değişkendir. Ancak eksik istihdamın ve işsizliğin yaygın olduğu ülkelerde öğrenim düzeyinin yüksek olması SED'in de yüksek olduğunun göstergesi olmayabilir ${ }^{5}$. Eşitsizlikte davranışsal yaklaşıma göre bilgiye erişim ile sigara kullanımı, sağlıksız beslenme, alkol tüketimi gibi risklerden korunma ve nitelikli sağllk hizmetine erişim arasında ilişki olduğu kabul edilir ${ }^{14}$. Çalışmalarda öğrenim değişkeni tamamlanmış öğrenim yıll, mezun olunan okul, diploma varlığı, mesleki eğitim alma, hanenin ortalama öğrenim düzeyi biçiminde alınır. Her öğrenim yılının SED'e benzer ölçüde katkısı olacağı gerekçesiyle örgün eğitimde tamamlanmış öğrenim yılı sık kullanılan değişkenlerden biridir. Tamamlanmış öğrenim yılı sürekli bir değişken olarak alınabileceği gibi kategorik biçimde de analiz edilebilir. Öğrenimin ikinci kullanım biçimi diploma gibi özel edinimlerin önemli olduğu gerekçesiyle mezun olunan okuldur. Öğrenim özellikle yaşlı çalışmalarında yaşlıların öğrenim 
durumlarının birbirine yakın olması nedeniyle diploma varlığına göre (var ya da yok olarak) gruplandırılır. Hanenin ortalama öğrenim düzeyi hane reisinin öğrenim düzeyine ya da hanede gelir getirici işte çalışan bireylerin ortalama öğrenim düzeyine göre belirlenir. İkinci yöntemde hanede çalışan kişilerin en son mezun oldukları okul ve bu okullara göre öğrenim yılları toplanıp kişi sayısına bölünerek elde edilir ${ }^{15}$.

SED'i belirlemede kullanılan ikinci değişken gelirdir. Gelir özetle maddi mallara ulaşımdaki farklılığı gösterir. Eşitsizliğe materyalist yaklaşıma göre yüksek gelirli kişilerin sağlıklı, güvenli konutlara ve gıdaya, nitelikli sağlık hizmetlerine erişim olasılığının yüksek olduğu, bu etmenlerin de sağlık durumunu ve mortaliteyi etkilediği belirtilir14. Gelirin SED değişkeni olarak kullanılmasındaki başlıca sorunlar; kişilerden gelire ilişkin güvenilir bilgi alınamaması ve yüksek gelir düzeyine sahip olmanın saygın bir mesleki konum ya da yüksek öğrenim düzeyi göstergesi olmamasıdır. Gelir aylık ya da yıllık hane geliri, kişibaşı gelir, gelir algısı, finansal birikim, yoksulluk olarak ölçülebilir. Kişibaşı gelir genellikle aylık toplam hane gelirinin kişi sayısına bölünmesiyle elde edilir. $\mathrm{Bu}$ durumda evde yaşayan kişiler yetişkin olsun ya da olmasın herkesin ağırlığı -bir- olarak kabul edilir. Bazı kişibaşı gelir hesaplarında birinci yetişkinden sonraki kişiler ya da çocuklar farklı ağırlıklandırılır. Örneğin Oxford Ölçeği'nde birinci yetişkin 1.0, diğer yetișkinler 0.7, 18 yaş altı bireyler 0.5 katsayı ile çarpılır, elde edilen toplam sayı hanenin toplam gelirine bölünür16. Gelir algısı "Günlük giderlerin için yeterli paran olduğunu düşünüyor musun?", "Sahip olduğunuz gelirle nasıl geçiniyorsunuz?", "Gelirin giderine göre nasıl?" gibi sorularla belirlenir 17-18. "Ekonomik nedenlerle okula gönderemediğiniz hiç çocuğunuz oldu mu?" sorusu da ekonomik durumu dolaylı olarak belirlemede kullanılan sorulardandır ${ }^{19}$. Finansal birikim özellikle yaşlılarda emeklilikle birlikte gelirin düşmesi ve kişilerin gelirleri arasındaki farkın azalması nedeniyle kullanılması önerilen değişkendir. Bu değişken belirlenirken birikim/fon/bono ile gayrimenkul/kiralık emlak varlığı değerlendirmeye alınır ${ }^{20}$. Bir başka ekonomik durum değişkeni "yoksulluk"tur. Yoksulluk mutlak, göreli ya da öznel yoksulluk tanımlarına göre belirlenir ${ }^{15}$.

SED değişkenlerinden üçüncüsü meslektir. Meslek kişilere öğrenim ve gelirin getirileri ile mesleki konumun kazandırdığı teknik beceri ve statüyü sağlar. Kişilerin yaptığı işin ellerindeki sermaye, mal ve taşınmazlara ilişkin mülkiyet konumlarını belirlemekten uzak olması nedeniyle, mesleği bir SED değişkeni olarak kullanırken aynı meslek içinde nesnel konum farklılıklarını belirlemek önemlidir. Örneğin mesleği hekimlik olan bir kişinin ücretli ya da kendi muayenehanesine sahip yani kendi hesabına çalışan ya da işveren konumunda olup olmadığının belirlenmesi önemlidir5. Meslekten yola çıkarak sıklıkla Weberci yaklaşımın sonucu olarak "Ulusal Mesleki Sınıflamalar" ve Amerikan ekolünün uzantısı olarak oluşturulan "Mesleki Saygınlık Ölçekleri" kullanılır. Mesleki saygınlık ölçeklerinin başlıcaları Duncan ve Treiman'ın Standart Uluslararası Mesleki Saygınlık ölçekleridir. Türkiye'de genellikle Kasnakoğlu-Erdil Mesleki Saygınlık Ölçeği kullanılır ${ }^{21}$.

Bireylerin üretim araçlarına sahip olup olmamalarına göre belirlenen ve Türkiye'de yapılan eşitsizlik çalışmalarında sıklıkla kullanılan sosyal sinıfa örnek Korkut Boratav'ın sinıflamasidır. Korkut Boratav kentsel ve kırsal alan için iki farklı sınıflama yapmıştır22. Ayrıca Erick O. Wright, Marksist kurama göre iyelik; iş ve öğrenime göre nitelik; yönetici, idareci ve işçi olmaya göre örgütsel boyutları belirleyerek 12 sınıf oluşturmuştur ${ }^{23}$.

Sinif genellikle hane reisinin (erkeğin ya da hanede en çok gelir getiren veya statüsü en yüksek olan kişi) ya da kişinin kendisinin o anda, en uzun süre ya da yaşam boyu yaptığı işe göre belirlenir. Sinıf belirlenirken dört grupta sorun yaşanır: Emekliler, işsizler, çocuklar ve ev kadınları. Emekliler ayrı bir grup olarak alınabileceği gibi, emekli oldukları ya da en uzun süre yaptıkları iş üzerinden de değerlendirmeye alınır. İşsizler ayrı grup kabul edilebileceği gibi en uzun süre 
yaptıkları ya da en son yaptıkları iş üzerinden de sınıflanır. Ev kadınları ayrı bir grup olarak alınabilir ya da herhangi bir dönemde yaptıkları en uzun süreli işe veya eşlerinin/ hane reisinin sınıfına bağlı olarak gruplanır. Çocuklar genellikle anne-babanın sosyal sınıfı ya da aile varsıllığına göre değerlendirilir. Çocuklarda sıklıkla kullanılan "Aile Varsıllığı Skoru"na göre ailenin araba ve bilgisayar sayısı, çocuğun kendine ait oda varlığı, geçen yıl aile ile tatil yapmış olmaya dayalı olarak üç SED grubu belirlenir 24. Eşitsizlikte "yaşam boyu yaklaşım" nedeniyle bireylerin o andaki sınıfları dışında doğumdaki ya da çocukluk dönemindeki sınıfları da bir değişken olarak alınabilir. $\mathrm{Bu}$ çalışmalarda kişilerin doğumunda ya da çocukluk döneminde babalarının ve/veya annelerinin SED'ine ya da yaşanılan evin özelliklerine göre sınıf belirlenir ${ }^{25}$. "Toplumsal hareketlilik" kavramına göre kişilerin kendi yaşam süresi içindeki ya da ailesine (özellikle babasına) göre toplumsal konumundaki değişim de bir değişken olarak alınabilir ${ }^{26}$.

$\begin{array}{ccc}\text { Çalışmalarda } & \begin{array}{c}\text { konut özellikleri, } \\ \text { gönvence }\end{array} & \text { durumu, yaşamı }\end{array}$ kolaylaştırıcı araçlar/dayanıklı tüketim mallarına sahip olma gibi yaşam standartlarını belirleyen dolaylı SED değişkenleri de kullanılır. Konut özellikleri konutun mülkiyetine, tipine (gecekondu, apartman dairesi, müstakil ev), yerleştiği alana (arsanın değeri), koşullarına (oda sayısı, odabaşına düșen kişi sayısı, ısınma ve içme suyu durumu, banyo ve ayrı yatak odası varlığı) göre belirlenir. Yaşlı çalışmalarında kullanılması özellikle önerilen değişkenlerinden biri evin mülkiyetidir. Sahip olunan yaşamı kolaylaştırıcı araçlar/dayanıklı tüketim malları hem SED'e hem de sağlık üzerindeki etkisine ilişkin bilgi verir ve ülkeden ülkeye değişen özellikler taşır. Örneğin İngiltere'de konut ve otomobil sahipliği; Nijerya'da motosiklet, bisiklet, radyo, buzdolabı, televizyon sahipliği ön planda olabilir27. $\mathrm{Bu}$ kapsamda hangi değişkenlerin alınacağına araştırmacı karar verebileceği gibi konunun uzmanları ile de karar verilebilir. Ulusal koşullara bağlı olarak etnik yapı, azınlık ya da göçmen olma, işsiz ya da sosyal yardım alan kişi olma özellikleri de dolaylı SED değişkeni olarak kullanılır.

Temel ya da dolaylı SED değişkenlerinin birarada kullanılmasıyla oluşturulan indeksler de bulunur. Hollingshead Sosyal Durum Indeksi'nde iş ve öğrenim; Warner'ın Statü Indeksi'nde iş, gelir kaynağı, ev tipi ve yaşanan bölgenin özellikleri; Census Bureau's SED Indeksi'nde gelir, öğrenim ve iş; VERİ-Sosyoekonomik Statü Indeksi'nde hane bireylerinin ortalama öğrenim düzeyi, çalışma konumları, sahip olunan yaşam kolaylaştırıcı araçlar, yaşanılan bölge ve ev sahipliği birarada kullanılarak her bir birey için tek bir SED sinıflaması yapılabilir 28-29. Çalışmalarda en üst ve en alttaki SED gruplarını dikkate alan Rölatif Eşitsizlik İndeksi ve Slope Eşitsizlik İndeksi de oldukça sık kullanılan değişkenlerdendir 5 . Değişkenler bireysel belirleyici olarak kullanılabileceği gibi bölgesel eşitsizliklerin belirleyicisi olarak da kullanılabilir. Carstair Yoksunluk Skoru, Townsend ve Neighborhood Yoksunluk Indeksleri bölgesel yoksunluk indeksine örnek gösterilebilir 18,30-31.

Ayrıca Şekil 5'de de görüldüğü üzere gelir dağllımıyla cinayetler ve güven duygusu arasındaki ilişki de incelenmektedir ${ }^{32}$.

\section{Sonuc}

Sağlıkta eșitsizlik, ekonomik, sosyal, kültürel, siyasal, sinıfsal ve benzeri nedenlerle bireylerde ve toplumun değişik kesimlerinde sağlıkla ilgili önlenebilir ve kabul edilemez farklılıkların oluşmasıdır. Sağlıkta eşitsizlikler bireysel değil toplumsal farklılıklardan kaynaklanır. Tüm dünyada giderek artan eşitsizlikler özellikle neoliberalizmin yaygınlaşmasından sonra günümüzün en önemli konularından birisidir ${ }^{33}$.

Eşitsizlik çalışmalarında hangi değişken kullanılırsa kullanılsın eşitsizliğin temelde sinıfsal farklılıklardan kaynaklandığı gözden kaçırılmamalıdır. $\mathrm{Bu}$ nedenle sağlıkta eşitsizlikleri azaltmanın yolu sınıfsal farklılıkları azaltmak, sağlık hizmetlerini daha ulaşılabilir ve kapsayıcı hale getirmek olmakla birlikte esas çözüm 
siniflı toplum yapisinin ortadan kaldırılmasıdır. Dolayısıyla sinifların ortadan kalkması eşit sağlık hizmetleri ve eşit toplum için şarttır. $\mathrm{Bu}$ durumda eşitsizliklerin yok edilmesi için ideolojik bir değişim gerektiği açıktır ${ }^{5}$. Kapitalist ideoloji eşitsizlikleri ortadan kaldıramaz. Çünkü bunun için önce kendisini ortadan kaldırması gerekir. Nitekim sağlıkta eşitsizlik çalışmalarında eşitsizliklerin

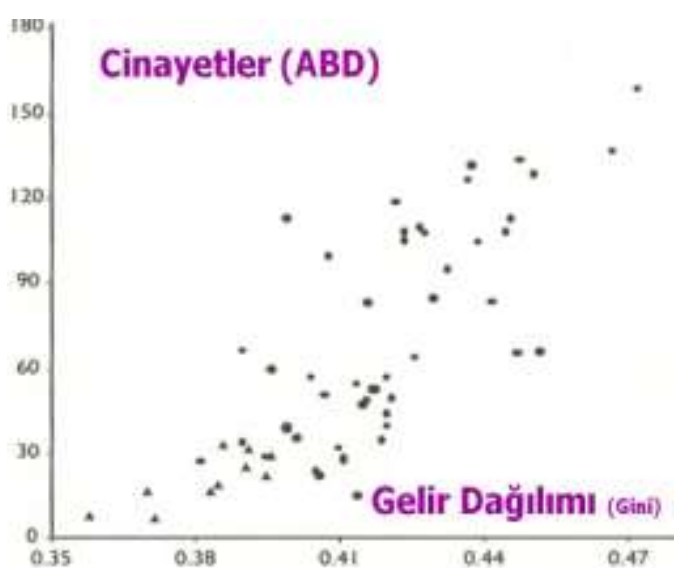

yalnızca sağlı hizmeti sunumu ile giderilemediği, sağlığın sosyal belirleyicileri üzerine toplumsal düzeyde girişimler yapılmasının da kesinlikle zorunlu olduğu gösterilmiştir. Çözüm toplumsal girişimlerde yatar ancak son kertede bu da yeterli değildir. $\mathrm{Bu}$ nedenle hem devletin ideolojik yapısı, hem politikalar hem de sağlı sisteminin yapısı günümüz toplumlarının en önemli konularıdır.

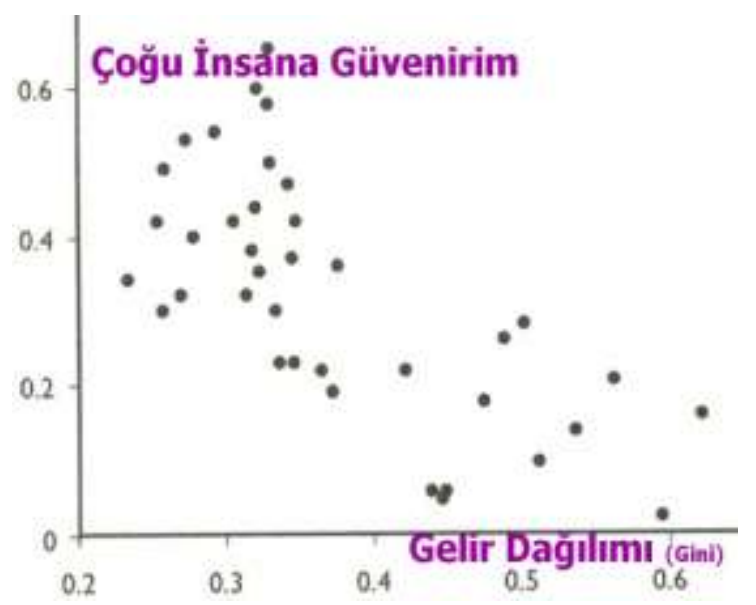

Şekil 5. ABD Eyaletlerinde Gelir Dağılımıyla Cinayetler ve Güven Duygusu Arasındaki İlişki

Kapitalist toplumlarda eşitsizliklerin azaltılması için yapılması gerekenler iki ana başlık altında özetlenebilir:

\section{Sağlığın sosyal belirleyicileri üzerine yapılması gerekenler}

a. Makroekonomik ve yeniden dağıtımcı politikalar

i. Eșitlikçi vergi sistemi kurulması (çok kazanandan çok vergi alınması),

ii. Emek politikalarını ön plana almak,

iii. Yeniden dağıtım mekanizmaları ile gelir dağılımını düzeltmek.

b. Sosyal insani gelişim yatırımlarına yönelik politikalar

i. Emeklilik, sağlık vb hakları çalışan lehine düzenlemek,

ii. Evrensel içerikli, parasız temel eğitim sağlamak, iii. Konut ve ulaşım altyapılarına yatırım ile herkese ucuz konut, ulaşım sağlamak,

iv. Beslenme, enerji-ısınma politikaları ile herkese ulaşmak.

2. Sağlık sistemi üzerine yapılması gerekenler

a. Herkese, ücretsiz kapsaml, nitelikli sağlık hizmeti sağlamak

b. Sağlığı koruma, geliștirme politikalarına ağırlık vermek
c. Temel sağlı hizmetlerini güçlendirmek

d. Toplum sağlığına, halk sağlığına önem veren bir sağlık sistemi oluşturmak

Nitekim günümüz kapitalist düzeninde sosyal devletler yukarıda verilen ilkeleri, girişimleri ön plana çıkaran devletler olmuştur. Ancak bu ülkelerdeki eşitsizlikler 
de aslinda temel sorunun devam etmesi nedeniyle sürüp gitmektedir. Bunun en iyi kanıtı kapitalist ideolojinin şiddetli savunucularından Dünya Sağlık Örgütü'nün (DSÖ) ve Dünya Bankası'nın hazırladığı raporlardır. Örneğin DSÖ, 2008 yılında Alma-Ata'nın 30. yılında yayınladığı "Dünya Sağlık Raporu”nda son 30 yılda sağlık alanında artan eşitsizliklere vurgu yaparak bir anlamda günah çıkartmıştır. Raporda eşitsizliklerle ilgili olarak Kenya'dan verilen örnekte Nairobi'nin yüksek gelirli bölgesinde 5 yaş altı çocuk ölüm hızı binde 15'in altında iken, aynı şehirde Emabakasi gecekondu bölgesinde 5 yaş altı çocuk ölümünün yaklașık 20 kat fazla olduğu vurgulaniyordu (binde 254). DSÖ raporu gelişmekte olan ülkelerde kent nüfusunun üçte birinin (1 milyardan fazla insan) gecekondularda yaşadığını ve aynı şehirde bir semtte yaşayan insanların ortalama

\section{Kaynaklar}

1. Çulhaoğlu M. Eşitsizlikler Kaçınılmaz midır? 3. Kent ve Sağlık Sempozyumu, 27-28 Mayıs 2011, Bursa.

2. Hamzaoğlu O. Eşitsizlikler Kaçınılmaz mıdır? 3. Kent ve Sağlık Sempozyumu, 27-28 Mayıs 2011, Bursa. s.30.

3. Türkbağ AU. Eşitsizlikler Kaçınılmaz midır? 3. Kent ve Sağlık Sempozyumu, 27-28 Mayıs 2011, Bursa. s.108.

4. Marks K. Kapital, Kapitalist Üretimin Eleștirel Bir Tahlili, Birinci Cilt. 3. Baskı. Eriş Yayınları, 2003

5. Belek İ. Sınıf, Sağlık, Eşitsizlik. İstanbul: Sorun Yayınları,1998.

6. Mills C. Equity and health: Key issues and WHO's role. Geneva: WHO/CHS/HSS/98.3, 1998.

7. Braveman P. Monitoring equity in health: A policy-oriented approach in low and middle income countries. Geneva: WHO/CHS/HSS/98.1, 1998.

8. WHO. Social Determinants of Health: The Solid Facts. (Marmot M, Wilkinson R (ed). 2nd ed.). Denmark: WA 30, 2003. yaşam süresinin 75 yılı geçtiği, oysa başka semtlerde yaşayanlarda bunun 35 yıla kadar indiği belirtilmektedir ${ }^{34}$. Ancak DSÖ, tüm bu gelişmelerde suçu sağlık sistemlerinin dünyanın son 30 yıldaki değişimine verdiği yanıtın yavaş ve yetersiz olmasına bağlamaktadır. DSÖ'nün suçu, başka nedenlerde bulması gerçek suçluyu gözlerden kaçırma amacına hizmet etmekten başka bir işe yaramamaktadır. Gerçek suçlu sağlık hizmetlerini bir meta haline getiren, sağlıkta serbest piyasa düzeni kurallarını uygulayan kapitalist düzendir. Kapitalizm, sağlıkta eșitsizliklerin artmasından gerçek anlamda sorumlu ideolojidir. Nitekim DSÖ de 2008 raporunda Küba sağlık sistemini ve sağlık politikasını toplumsal kaynakları harekete geçirmek ve insan kaynaklarını geliştirmek anlamında olumlu bir örnek olarak vermek zorunda kalmıştır ${ }^{34}$.

9. Whitehead M. The concepts and principles of equity and health. Copenhagen: EUR/ICP/RPD/414, 1990.

10. World Bank. World Development Report: Investing in Health. New York: Oxford University Pres, 1993.

11. Wilkinson R, Pickett K. The spirit level: Why greater equality makes societies stronger. New York: Bloomsbury Press, 2009.

12. Bambra C. Health inequalities and welfare state regimes:theoretical insights on a public health 'puzzle'. J Epidemiol Community Health 2011;65:740-745.

13. Galobardes B, Shaw M, Lawlor DA, Lynch JW, Smith GD. Indicators of socioeconomic position (part 1). J Epidemiol Community Health 2006;60:712.

14. Grundy E, Holt G. The socioeconomic status of older adults: How should we measure it in studies of health inequalities?. J Epidemiol Community Health 2001;55:895-904. 
15. TÜSİAD. Türkiye'de Gelir Dağılımı ve Yoksulluk. İstanbul: Lebib Yalkın Yayınları, 2000.

16. Rahkonen $\mathrm{O}$, Arber S, Lahelma $\mathrm{E}$, Martikainen $\mathrm{P}, \quad$ Silventoinen $\mathrm{K}$. Understanding income inequalities in health among men and women in Britain and Finland. Int $J$ Health Serv. 2000;30:27-47.

17. Cheng YH, Chi I, Boey KW, Ko LSF, Chou KL. Self-related economic condition and health of elderly persons in Hong Kong. Soc Sci Med 2002;55:1415-1424.

18. Lawlor DA, Tooth L, Lee C, Dobson A. A comparison of the association between socioeconomic position and cardiovascular disease risk factors in three age cohorts of Australian women: findings from the Australian Longitudinal Study on Women's Health . J Public Health 2005;27(4): 378-387.

19. Türkkan A, Aytekin H. Socioeconomic and healh inequality in two regions of Turkey. J Community Health 2009 (34):346-352.

20. Scho I, Huxhold O. Socioeconomic status and health in the second half of life: Findings from the German Ageing Survey. Eur J Ageing 2010;7:17-28.

21. Yardım MS, Cebeci H. Ankara İli Çankaya İlçesi'nde 25 yaş ve üzeri nüfusun sağlık düzeyinde sosyoekonomik farklılıklar. Ege Tip Dergisi 2010;49(1):19-30.

22. Boratav K. İstanbul ve Anadolu'dan sınıf profilleri. 2. Baskı. İstanbul: İmge Kitabevi, 2004.

23. Wright EO. Class counts: Comparative studies in class analysis: Student edition. Cambridge: Cambridge University Pres, 2000.

24. Boyce $\mathrm{W}$, Torsheim T, Currie C, Zambon A. The family affluence scale as a measure of national wealth: validation of an adolescent self-report measure. Soc Indic Res 2006; 78: 473-487.
25. Galobardes B, Smith GD, Lynch JW. Review of the influence of childhood socioeconomic circumtances on risk for cardiovasculer disease in adulthood. Annual Epidemiology 2006;16:91-104.

26. Kalaycıoğlu S. Toplumsal Tabakalaşma. Sosyolojiye Giriş kitabı içinde ed: Sezal İ. İstanbul: Beta Yayınları, 2010. s. 243292.

27. Onwujkwe 0 . Inequalities in healthcare seeking in the treatment of communicable endemic disease in Southeast Nigeria. Soc Sci Med 2005;61:455-63.

28. The changing American Society: Demographics and social stratification. Erişim adresi: http://www.scribd.com/doc/36658785 /4-Demographics, erişim tarihi: 30.03.2011.

29. VERİ SESİ. Erişim adresi: http://www.veriarastirma.com/sag.asp? kat=22., erişim tarihi: 12.05.2008.

30. Winkleby $M$, Sundquist $\mathrm{K}$, Cubbin $\mathrm{C}$. Inequalities in CHD incidence and case fatality by neighborhood deprivation. Am J Prev Med 2007;32(2):97-106.

31. Northern and Yorkshire Cancer Registry and Information Service. Townsend material deprivation index scores by ward. Erişim adresi. http://www.nycris.org.uk/reports/ineq ual/inequal cancer townsend.pdf., erişim tarihi: 15.05.2008.

32. Wilkinson $R$ (2005) The impact of inequality:How to make sick societies healthier. The New Press, USA, s:42,48

33. Navarro V. Neoliberalism, globalization and inequalities. New York: Baywood Publishing, 2007.

34. WHO. The World Health Report 2008, Primary Health Care- Now More Than Ever. Geneva, Switzerland: 2008. 